\title{
EVALUASI PENERAPAN PRINSIP AKUNTANSI SUBSTANSI MENGUNGGULI BENTUK FORMAL PADA STANDAR AKUNTANSI PEMERINTAH OLEH BPK PERWAKILAN PROVINSI SULAWESI UTARA TERHADAP PEMERIKSAAN LAPORAN KEUANGAN PEMERINTAH DAERAH
}

\author{
Maruli Harry Siregar \\ Grace B. Nangoi \\ Lintje Kalangi
}

(Email: maruli_regar@yahoo.com)

\begin{abstract}
This study used a qualitative method of ethnography aimed Evaluation Accounting Principles Substance Over Form Formal perform On Government Accounting Standards By BPK Representative Province of North Sulawesi on Auditing of Local Government Finance Statement. Data collected by interviews and observations of key informants comprising five LKPD team leader. The results showed that the examiner shows sometimes there are variations in interpreting the six cases of substance over form in government accounting standards in the auditing of financial statements of the government. The lack of common ground in the assessment of the examiner, showed that in accounting principles-based approach to standard setting which assumes that the professional judgment by the examiner is uniform on each examination is a very difficult thing to do. It can affect the implementation of the tasks inspectors in carrying out the examination of financial statements of the government.
\end{abstract}

Key Word: Auditing, LKPD, Substance Over Form, BPK

\section{PENDAHULUAN}

Akuntansi pemerintahan merupakan salah satu jenis akuntansi yang sedang berkembang. Akuntansi pemerintahan di Indonesia berkembang dimulai sejak ditetapkannya Peraturan Pemerintah Nomor 24 Tahun 2005 tentang Standar akuntansi Pemerintah. Peraturan Pemerintah tersebut kemudian diubah dengan Peraturan Pemerintah nomor 71 tahun 2010.

Pemeriksa BPK dalam melakukan pemeriksaan atas laporan keuangan pemerintah daerah harus memperhatikan penyajian akun-akun dalam laporan keuangan tersebut. Pemeriksa harus melihat kesesuaian akun tersebut terhadap standar akuntansi pemerintah dan kecukupan pengungkapannya. Pemeriksa dihadapkan pada permasalahan untuk penyajian akun-akun pada laporan keuangan dibandingkan dengan kebijakan akuntansi dari masing-masing pemerintah daerah. Selain itu, pemeriksaan laporan keuangan juga mempertimbangkan suatu kewajaran akun dengan memperhatikan penerapan dari prinsip akuntansi substansi mengungguli bentuk formal.

Yongtao Hong (2008) menyebutkan There is a general belief in the financial community and in policy discussions that principles-based standards, if applied properly, improves the quality of accounting information by focusing on economic substance of transactions over form, discouraging financial structuring and same accounting treatment for dissimilar transactions.

Pendapat Yongtao Hong tersebut menjelaskan bahwa terdapat pandangan umum dibidang keuangan yang berpendapat bahwa standar yang berdasarkan prinsip-prinsip akuntansi bila diterapkan secara baik akan meningkatkan kualitas dari informasi-informasi akuntansi terutama dengan berfokus kepada substansi ekonomi dari suatu transaksi dibandingkan dengan bentuk formal transaksi tersebut. Pandangan tersebut hendaknya dapat menjadi acuan bagi pemeriksa BPK dalam melakukan pemeriksaan laporan keuangan. Pemeriksa BPK harus memperhatikan penerapannya dalam akuntansi pemerintahan. Akuntansi pemerintahan sesuai cirinya harus menyesuaikan dengan struktur organisasi pemerintahan. Sehingga dalam akuntansi pemerintahan juga harus memperhatikan peraturan-peraturan pemerintah lainnya. Pemeriksa tidak hanya memperhatikan Peraturan Pemerintah nomor 71 tahun 2010 tentang Standar Akuntansi Pemerintahan.

Pemeriksaan yang dilaksanakan oleh BPK RI Provinsi Sulawesi Utara saat ini semakin menjadi perhatian masyarakat, karena Laporan keuangan menjadi salah satu indikator kinerja dari pemerintah daerah. Bahwa berdasarkan hasil pemeriksaan terhadap Laporan Keuangan Pemerintah Daerah (LKPD), BPK menemukan masih adanya temuan yang merugikan keuangan negara di Provinsi Sulawesi Utara, dan di sejumlah kabupaten/kota lain 
pada tahun 2010 -2014 bahkan di beberapa kabupaten dan kota masih mendapat opini tidak wajar atau tidak memberikan pendapat. Dalam laporan keuangan tersebut ditemukan masih adanya temuan-temuan berupa ketidakpatuhan terhadap peraturan perundang-undangan, kecurangan, ketidakpatuhan dalam pelaporan keuangan dan lemahnya pengendalian intern. Temuan BPK tersebut, salah satunya didasarkan substansi dari akun-akun pada laporan keuangan yang ada di kabupaten/ kota Sulawesi Utara masih kurang baik. Peneliti tertarik dengan penelitian substansi mengungguli bentuk formal pada Kantor BPK RI Perwakilan Sulawesi Utara dengan alasan karena BPK perwakilan Sulawesi Utara melakukan pemeriksaan untuk permasalahan-permasalahan yang ada di Provinsi Sulawesi Utara serta 15 kabupaten/kota dan permasalahan tersebut dapat memiliki substansi yang sama serta dapat mempengaruhi opini laporan keuangan . Selain itu peneliti juga ingin mengetahui tentang konsistensi dari pemeriksaan tentang akun-akun tertentu yang memiliki substansi permasalahan yang sama diantara Provinsi Sulawesi Utara serta 15 kabupaten/kota yang dilakukan pemeriksa dalam meningkatkan kualitas laporan keuangan pemerintah daerah. Kejadian yang dihadapi pemeriksa tersebut mendorong peneliti untuk melakukan penelitian dengan judul "Evaluasi Penerapan Prinsip Akuntansi Substansi Mengungguli Bentuk Formal Pada Standar Akuntansi Pemerintah Oleh BPK Perwakilan Provinsi Sulawesi Utara Terhadap pemeriksaan Laporan Keuangan Pemerintah Daerah".

\section{TINJAUAN PUSTAKA}

\subsection{Substansi mengungguli bentuk formal (Substance Over Form)}

Pada Peraturan Pemerintah nomor 71 tahun 2010 substansi mengungguli bentuk dijelaskan sebagai Informasi yang dimaksudkan untuk menyajikan dengan wajar transaksi serta peristiwa lain yang seharusnya disajikan,maka transaksi atau peristiwa lain tersebut perlu dicatat dan disajikan sesuai dengan substansi dan realitas ekonomi, dan bukan hanya aspek formalitasnya. Apabila substansi transaksi atau peristiwa lain tidak konsisten/berbeda dengan aspek formalitasnya, maka hal tersebut harus diungkapkan dengan jelas dalam Catatan atas Laporan Keuangan.

Menurut Suwardjono (2011, 243) Substansi daripada bentuk dijelaskan sebagai konsep yang menyatakan bahwa dalam menetapkan suatu konsep di tingkat perekayasaan atau dalam menetapkan standar di tingkat penyusunan standar, akuntansi akan menekankan makna atau substansi ekonomik suatu objek atau kejadian daripada makna yuridisnya meskipun makna yuridis mungkin menghendaki atau menyarankan perlakukan akuntansi yang berbeda.

Ong dan Spink $(2004,199)$ menjelaskan dalam konstruksi abstrak, doktrin substansi mengungguli bentuk formal menegaskan prevalensi prinsip keadilan dan kewajaran atas ketentuan yang saling bertentangan dari common law, sehingga dapat membuat kontribusi penting untuk kelancaran keseluruhan sistem hukum. Ekuitas tradisional melihat substansi (substance), bukan pada bentuk (form) bertele-tele dari suatu transaksi. Dijelaskan pula bahwa substansi mengungguli bentuk formal berasal dari hukum tanah dan bila tidak terdapat kecurangan, kesalahan, keliruan, atau penyembunyian sifat sebenarnya dari suatu transaksi, doktrin substansi mengungguli bentuk formal tidak akan membatalkan hukum umum atas hak kontraktual para pihak yang bekerja sama secara bebas dan sah. Hal tersebut sejalan dengan pendapat Eaton dan rout yang menyatakan bahwa subtansi dari transaksi merupakan yang terpenting dibandingkan dengan bentuk formal yang akan mendukung perkembangan serta penerapan dari standar akuntansi itu sendiri.

Eaton and Rout $(1999,3)$ menyebutkan: The concept that the economic substance of transactions should be paramount over the legal form of accounting transactions is integral to the development and application of accounting standards". Statement of financial accounting Concepts (SFAC) No. 2 dalam Eaton and Rout (1999) menyebutkan "The quality of reliability, and in particular, representational faithfulness leaves no room for accounting representations that subordinate substance to form"

\section{Kerangka Konseptual Penelitian}

Pemerintah daerah memiliki kewajiban untuk menyerahkan laporan keuangan pemerintah daerah kepada BPK. Pemeriksa dalam pemeriksaannya dapat menemui kasus - kasus atas suatu penyajian akuntansi pada laporan keuangan. Kasus - kasus penyajian akuntansi tersebut berdasarkan penilaian profesional pemeriksa akan dilihat mengacu pada standar akuntansi pemerintah.

Terkadang pemeriksa harus melihat kepada prinsip akuntansi yang dapat diterapkan pada kasus tersebut dan salah satu yang banyak digunakan adalah prinsip substansi mengungguli bentuk formal. Namun pemeriksa juga menghadapi kendala atas penerapan prinsip substansi mengungguli bentuk formal yang disebabkan akuntansi pemerintah juga harus memperhatikan peraturan perundang - undangan yang berlaku. Penelitian ini didesain untuk mengetahui bagaimanakah pendapat pemeriksa atas penerapan prinsip akuntansi substansi mengungguli bentuk formal pada akuntansi pemerintahan. 
Kerangka pemikiran ini digunakan untuk mempermudah jalan pemikiran terhadap masalah yang akan dibahas. Seperti telah disebutkan sebelumnya peneitian ini bertolak dari pengalaman peneliti sebagai pemeriksa terhadap prinsip akuntansi substansi mengungguli bentuk formal. Penerapan prinsip substansi mengungguli bentuk formal dilakukan dalam pemeriksaan laporan keuangan pemerintah daerah. Peneliti akan terlebih dahulu melihat produk-produk yang dihasilkan pemeriksa BPK berupa laporan hasil pemeriksaan. Atas laporan hasil pemeriksaan tersebut dilakukan penelaahan atas akun -akun yang ada didalam neraca dan laporan realisasi anggaran. Hasil review dari permasalahan pada neraca dan laporan realisasi anggaran kemudian diresume untuk digunakan sebagai bahan wawancara terhadap pemeriksa BPK. Peneliti akan melakukan wawancara kepada masing masing pemeriksa untuk ditanyakan pendapat mengenai substansi mengungguli bentuk formal, Pendapat atas kasus pada akun neraca dan pendapat pemeriksa atas kasus di akun laporan realisasi anggaran.

Kerangka pemikiran ini dikaitkan untuk mengetahui pendapat dari responden penelitian atas kasus - kasus yang terjadi pada prinsip substansi mengungguli bentuk formal. Penelitian ini ingin memahami pendapat pendapat dari masing -masing pemeriksa untuk kasus substansi mengungguli bentuk formal pada akun pada neraca adalah kas, piutang, investasi, dan aset tetap, sedangkan pada laporan realisasi anggaran adalah PAD dan belanja modal.

\section{ANALISIS DAN PEMBAHASAN HASIL PENELITIAN}

\subsection{Substansi mengungguli bentuk formal pada neraca}

Penelitian memilih empat contoh akun pada neraca yang dapat menggunakan prinsip substansi mengungguli bentuk formal yang diharapkan cukup untuk menjelaskan pendapat pemeriksa yang dikembangkan di tesis ini. Selain itu, dengan membatasi pada empat kasus substansi mengungguli bentuk formal ini, penelitian dapat dilakukan dalam tempo yang relatif singkat dan dengan demikian responden dapat memberikan jawaban yang wajar.

Pada kas pemerintah terdapat beberapa kasus yang dapat dilihat pada laporan hasil pemeriksaan atas laporan keuangan pemerintah daerah. Pada kas bendahara pengeluaran SKPD Bolaangmongondow Selatan TA 2013 tidak termasuk kas yang merupakan belanja yang belum dibayarkan kepada pihak ke III. Pada kas bendahara pengeluaran Kabupaten Bolaang Mongondow TA 2013 terdapat Kas yang tidak nyata karena telah digunakan yang mengakibatkan kerugian daerah namun atas hal tersebut dananya tetap dicatat sebagai kas di bendahara pengeluaran. Pada LKPD Kota Tomohon TA 2013 untuk kas yang tidak nyata dipindahkan ke akun aset lainnya berdasarkan keterangan di CaLK. Pada LKPD Kota Manado TA 2013 terdapat kas di bank yang berbeda dengan kas pembukuan karena terdapat penerbitan SP2D yang dicairkan melewati TA 2014 untuk kemudian diakui sebagai belanja walaupun kas belum keluar dari kas daerah. Pada LKPD Kabupaten Minahasa Tenggara terdapat temuan kas tidak nyata pada bendahara pengeluaran SKPD namun tetap disajikan sebagai kas di bendahara pengeluaran.

Pemeriksa BPK menjelaskan kas tersebut sebenarnya formal dan substansi adalah sama seharusnya. Secara formal kas harus liquid.. Secara formal harus dia ada catatan pada BKU. untuk kas di bendahara pengeluaran seharusnya hanya untuk menyajikan kas yang berasal dari uang persediaan namun terkadang bendahara pengeluaran bisa saja menguasai uang yang lain selain itu terkadang pada kas bendahara pengeluaran uang telah tidak ada karena belum ada SPJ mengakibatkan harus tetap disajikan pada laporan keuangan walaupun secara substansi kas telah tidak ada

Seharusnya kas yang nyata-nyata dikuasai sebagai kas yang harusnya dicatat sebagai kas. Namun bila berdasarkan pemeriksaan tidak ada kas yang dikuasai maka seharusnya atas kas tersebut tidak disajikan pada laporan keuangan. Pada laporan keuangan seharusnya dilakukan jurnal koreksi namun selain itu juga harus dilakukan penelaahan atas kepatuhan yang harus kita ungkapkan. Kas itu dicatat pada saat kas itu dikuasai sebagai substansinya. Kas pada intinya uang yang digunakan untuk kegiatan pemerintahan.

Untuk kas bendahara pengeluaran yang sudah tidak ada. Secara formal diakui berdasarkan pencatatan yang dilakukan oleh bendahara pengeluaran. Atas hal tersebut tidak dilakukan koreksi namun diungkapkan didalam CaLK dan diungkapkan dalam Temuan kepatuhan. Selain itu pada panduan pemeriksaan BPK bila kas tidak ada namun telah ada putusan pengadilan maka atas kas tersebut tetap dicatat dan diungkapkan pada kas di bendahara pengeluaran. Apalagi terdapat indikasi kerugian daerah. Atas hal tersebut tidak dilakukan koreksi. Hal ini juga harus memperhatikan tingkat materialitas.

Pemeriksa pada umumnya sepakat bahwa kas harus disajikan sesuai substansinya yaitu kas tersebut ada dan dikuasai oleh pemerintah daerah namun apabila terdapat kasus kas hilang namun tetap disajikan pada Laporan keuangan Pemeriksa memiliki pendapat yang berbeda atas hal tersebut. Terdapat pemeriksa yang melakukan koreksi atas kas tersebut namun ada pula yang hanya mengungkapakan dalam temuan kepatuhan.

Atas berbagai pendapat pemeriksa atas kasus - kasus pada kas harus dilihat kembali apakah yang dimaksud sebagai kas. Kas sesuai pengertiannya pada PSAP adalah uang tunai dan saldo simpanan di bank yang setiap saat dapat digunakan untuk membiayai kegiatan pemerintahan. Berdasarkan definisi tersebut, wujud kas 
dapat dibedakan atas uang tunai dan saldo simpanan di bank. Kas berupa uang tunai, terdiri atas uang kertas dan logam dalam mata uang rupiah dan mata uang asing yang dikuasai oleh pemerintah. Kas berbentuk saldo simpanan di bank adalah uang pada seluruh rekening bank yang dikuasai pemerintah yang dapat digunakan setiap saat. Sehingga dapat diartikan secara substansi kas harus dikuasai pemerintah dan dapat segera digunakan oleh pemerintah bukan hanya berupa pencatatan di buku kas yang dilakukan pemerintah. Dalam hal pemeriksa menemukan terdapat perbedaan antara pencatatan pada buku kas dengan saldo nyata kas maka pemeriksa harus kembali kembali ke substansi dari kas tersebut yaitu uang yang dikuasai dan dapat segera digunakan. Penyajian kas sewajarnya sesuai dengan nilai nyata yang dikuasai pemerintah. Atas nilai kas yang berbeda tersebut dapat dilakukan koreksi dengan cara bila nilai kas yang nyata melebihi nilai pada pencatatan maka atas kas yang melebihi kas tersebut dilakukan pencatatan untuk menambah nilai catatan pad akas. Apabila terdapat selisih kurang atas nilai nyata yang kurang dari pencatatan kas maka pencatatan di kas dikoreksi sesuai dengan nilai nyata kas dan nilai koreksi dapat dimasukkan ke nilai asset lainnya pada laporan keuangan. Setelah dilakukan koreksi sesuai dengan pendapat pemeriksa maka pada catatan atas laporan keuangan dapat diungkapkan secara memadai sesuai dengan kondisi yang terjadi. Pemeriksa juga dapat menambahkan permasalahan tersebut sebagai bagian dari temuan pmeriksaan yang merupakan bagian yang tidak terpisahkan dari laporan hasil pemeriksaan atas laporan keuangan pemerintah daerah.

Piutang lancar secara formal yang kolektibilitasnya harus dibawah 12 bulan. Piutang selama ini disajikan secara nilai tercatat saja karena selama ini belum dibuat aging schedule. Pencatatan piutang harus diakui berdasarkan pengakuan yang ada terlebih dahulu. Piutang merupakan hal yang harus diterima pemerintah daerah berdasarkan suatu perikatan atau peraturan. pemeriksa harus meminta pemerintah daerah untuk menyajikan dokumen piutang tersebut.

Salah satu cara untuk meyakinkan substansi piutang itu adalah secara konfirmasi kepada pihak ke 3 yang lebih yakini sebagai bukti. Kita juga harus memilah piutang seperti apa yang harus dikonfirmasi. Untuk piutang kepada negara kita tidak perlu melakukan konfirmasi seperti piutang pajak yang bersifat memaksa kecuali piutang atas perikatan. Jadi sebenarnya dapat disajikan berdasarkan aging schedule, agar bisa dilihat kolektibilitasnya cukup tinggi. piutang itu sendiri untuk diakui harus didukung atas formalnya misalkan untuk TGR maka harus didukung SKTJM. Sedangkan untuk piutang yang lain seperti piutang PBB juga harus didukung dengan buktibukti yang jelas. Jadi tetap formalnya harus ada terlebih dahulu. Setelah piutang telah diyakini pengakuannya baru dilihat tingkat keraguan atas kolektibilitas pembayarannya.

Pada piutang pemerintah terdapat beberapa kasus yang dapat dilihat pada laporan hasil pemeriksaan atas laporan keuangan pemerintah daerah. Pada LKPD Kabupaten Minahasa TA 2013 terdapat temuan piutang yang tidak didukung dokumen yang lengkap yang berakibat nilai piutang pada neraca tidak menunjukkan kondisi yang sebenarnya. Dalam melakukan pemeriksaan kita melakukan pemeriksaan atas asersi yang salah satunya adalah keberadaan. Perlakuan akuntansi seharusnya disajikan berdasarkan nilai yang dapat diterima setidaknya diungkapkan pada CaLK. Jadi atas piutang macet tidak perlu dikoreksi dan hanya diungkapkan pada CaLK. Kemudian pemeriksa hanya mengungkapkan dalam temuan kepatuhan. Dalam hal ini tergantung dari pemerintah daerah apakah ingin melakukan penghapusan atau tidak. Namun dalam proses penghapusan harus memperhatikan peraturan yang ada. Jadi kita tidak bisa langsung melakukan penghapusan. Apalagi dalam proses penerbitan piutang sudah sesuai prosedur.

Atas permasalahan tentang piutang maka dilihat kembali definisi aset menurut PSAP 01 tentang Penyajian Laporan Keuangan yaitu sumber daya ekonomi yang dikuasai dan/atau dimiliki oleh pemerintah sebagai akibat dari peristiwa masa lalu dan dari mana manfaat ekonomi dan/atau sosial di masa depan diharapkan dapat diperoleh, baik oleh pemerintah maupun masyarakat, serta dapat diukur dalam satuan uang, termasuk sumber daya nonkeuangan yang diperlukan untuk penyediaan jasa bagi masyarakat umum dan sumber-sumber daya yang dipelihara karena alasan sejarah dan budaya. Selanjutnya khusus mengenai piutang, pada paragraf 49 PSAP 01, dinyatakan bahwa Neraca mencantumkan sekurang-kurangnya piutang pajak dan bukan pajak. Piutang sesuai Buletin teknis nomor 6 tentang piutang harus dipenuhi kriteria 1. Telah diterbitkan surat ketetapan dan/atau 2 . Telah diterbitkan surat penagihan dan telah dilaksanakan penagihan. Selanjutnya terhadap pengakuan timbulnya hak tagih atas pungutan pendapatan negara/daerah, perikatan, tuntutan ganti rugi serta akibat keputusan pengadilan. Selama ini hanya pengakuan dan pencatatan piutang berdasarkan nilai nominal saja, tanpa memperhitungkan kolektibilitas sesuai dengan sifat dan karakteristik debitur. Secara substansi piutang termasuk dalam aset lancar sehingga diharapkan segera untuk direalisasikan dalam waktu 12 (dua belas) bulan sejak tanggal pelaporan. Jadi penyajian piutang hanya merupakan tagihan yang harus dilunasi oleh para wajib bayar pada periode berjalan tahun berikutnya, selain itu penetapan piutang tersebut harus didukung oleh bukti-bukti yang kuat, dan limit waktu pelunasan tidak melebihi satu periode akuntansi berikutnya sehingga tidak ada piutang jenis ini yang melampaui satu periode berikutnya dan disertai dengan penyisihannya. Pengakuan piutang sewajarnya baru dilakukan setelah 
terdapat surat ketetapan. Atas permasalahan piutang tersebut dapat ditambahkan penjelasan pada Catatan atas Laporan keuangan dan pada temuan pemeriksaan.

Pemeriksa BPK menjelaskan formal investasi adalah penyertaan modal ke entitas lain. seharusnya bentuk formal sesuai dengan peraturan daerah dan bukti yang dimiliki. Kita harus melihat dahulu apakah telah disertai dengan perda penyertaan modal terlebih dahulu. Bila penyertaan modal berupa aset maka nilai aset pemerintah daerah yang diserahkan harus terlebih dahulu dikeluarkan dari pencatatan pemerintah daerah baru dapat dicatat di LK BUMD .

Untuk meyakini substansinya harus di cek keberadaan dan kelengkapannya. Terkait pengunaan metode pencatatan investasi harusnya diatur dalam kebijakan akuntansi. Pertama kita harus mengetahui persentase kepemilikan dari entitas investasi itu lalu di cek pula apakah pemerintah daerah memiliki pengendalian atas entitas investasi tersebut. Namun bila sesuai substansi maka seharusnya dengan persentase dari investasi itu sendiri jadi bila dimiliki secara keseluruhan maka seharusnya disajikan dengan metode ekuitas

Investasi contohnya pada PDAM terkadang yang dilimpahkan adalah aset terkadang nilai penyertaan modal belum jelas. Terkadang belum diakui atas nilai asetnya. Sebagai pemeriksa kita hanya bisa diungkapkan dalam temuan karena tidak mengetahui nilai investasi yang secara wajar. Jadi belum bisa kita koreksi karena belum tahu nilai aset yang telah diserahkan ke PDAM. Namun bila terdapat perbedaan pencatatan investasi bila kita yakin maka kita dapat melakukan koreksi. Bila cost method ada bukti maka dilakukan koreksi. Terkait persentase tinggi maka bisa saja kita melakukan koreksi sesuai metode pencatatan. pertama kita harus melihat persentase kepemilikan dari investasi itu sendiri. Bila kita dapat melakukan koreksi maka kita bisa melakukan koreksi atas nilai investasi itu sendiri. Bila dicatat di kedua sisi pemda dan BUMD maka dijadikan temuan kepatuhan. Koreksi hanya bila pencatatan sudah jelas dan diungkapkan dalam CaLK.

Untuk investasi pemeriksa berpendapat bahwa substansi tetap diutamakan dimana dilihat dari persentase kepemilikan dan pengaaruh dari pemerintah atas invetasi tersebut. Namun atas hal tersebut harus juga diperjelas atas Perda atas penyertaan modal serta nilai penyertaan modal tersebut. Pemeriksa tidak dapat melakukan koreksi apabila nilai penyertaan modal tidak jelas.

Investasi berupa penyertaan modal merupakan bagian dari investasi jangka panjang. Secara substansi nilai investasi didapat dari biaya perolehannya yang meliputi harga transaksi investasi itu sendiri ditambah biaya lain yang timbul dalam rangka perolehan investasi tersebut. Namun demikian dalam penyajian pada laporan keuangan harus dilihat kembali persentase kepemilikan dan pengaruh signifikan atas penyertaan modal tersebut. Jadi pengakuan atas investasi dan metode yang digunakan akan bergantung pada substansi dari pengaruh signifikan dari pemerintah terhadap penyertaan modal tersebut.

Pemeriksa BPK menjelaskan aset tetap yang memiliki manfaat lebih dari 12 bulan. bila kita yakin bila barang itu ada maka kita tetap harus mencatat. Untuk substansinya kita harus memperhatikan keberadaan selain itu kita harus melihat threshold kapitalisasi terkadang ada aset yang masuk seharusnya barang habis pakai. aset tetap seharusnya disajikan berdasarkan substansi namun selama ini masih mengakomodir aspek formal contohnya atas pencatatan aset - aset yang telah tidak ada karena belum memiliki SK penghapusan sehingga masih tetap dicatat pada laporan keuangan atas hal tersebut harusnya diungkapkan pada CaLK. selama ini kita melihat dari substansi dari aset itu sendiri. Kita melihat apakah atas aset itu sendiri bentuknya ada atau tidak. Bila aset terebut tidak ada atau telah rusak berat maka seharusnya disarankan untuk dilakukan penghapusan. Untuk aset yang belum sertifikat maka disarankan untuk dilakukan proses sertifikat.

Terkait barang yang hilang kita harus memperhatikan prosedur penghapusan kita tidak bisa serta merta melakukan penghapusan tetapi kita juga harus melakukan review ulang atas kehilangan tersebut. Pemeriksa tidak melakukan koreksi namun diungkapkan dalam temuan kepatuhan. Pemeriksa seharusnya membuat temuan kepatuhan atas kasus -kasus tersebut. Pemeriksa tidak bisa melakukan koreksi karena kewenangan penghapusan merupakan milik Bupati dan DPRD. Kita hanya menyarankan saja sesuai koreksi saja. Contohnya atas belanja modal yang telah diserahkan kita bisa koreksi saja karena telah diserahkan dan pemerintah daerah tidak dikuasai lagi oleh pemerintah daerah.

Pemerintah daerah tetap terlebih dahulu melakukan penelusuran atas aset tersebut dan dilakulan penilaian apakah penelusuran telah memadai. Apabila penelusuran memadai maka pemeriksa mengusulkan proses penghapusan atas aset-aset tersebut. Pemeriksa harus lebih konservatif dalam pemeriksaan, jangan sampai aset pemda hilang begitu saja karena tidak hati-hati dalam koreksi. Kita hanya mengungkapkan temuan kepatuhan. atas kasus-kasus tersebut harus dijadikan catatan pemeriksaan namun tidak dilakukan koreksi dan diungkapkan dalam CaLK.

Aset tetap sesuai pengertiannya aset berwujud yang mempunyai masa manfaat lebih dari 12 (dua belas) bulan untuk digunakan, atau dimaksudkan untuk digunakan, dalam kegiatan pemerintah atau dimanfaatkan oleh masyarakat umum. Dalam hal terdapat asset-aset dalam kondisi rusak berat atau hilang maka secara substansi aset tersebut bukan bagian dari aset tetap karena tidak dapat digunakan lagi oleh pemerintah. Aset tetap yang rusak 
berat dan hilang harus di koreksi dari aset tetap pada laporan keuangan menjadi bagian dari aset lainnya. Penghapusan aset tetap harus sesuai peraturan perundang-undangan sehingga apabila aset tetap yang akan dihapus dipindahkan terlebih dahulu ke aset lainnya agar sesuai dengan prosedur penghapusan yang akan dilakukan. Pada Catatan atas laporan keuangan dapat ditambahkan penjelasan atas aset tetap yang rusak berat, hilang, akan diserahkan pada pihak lain atau dokumen kepemilikannya belum lengkap.

\subsection{Substansi mengungguli bentuk formal pada Laporan Realisasi Anggaran}

Penelitian dilakukan atas dua akun pada laporan realisasi anggaran yang dapat menggunakan prinsip substansi mengungguli bentuk formal yang diharapkan cukup untuk menjelaskan pendapat pemeriksa yang dikembangkan di tesis ini.

Pada pendapatan pemerintah terdapat beberapa kasus yang dapat dilihat pada laporan hasil pemeriksaan atas laporan keuangan pemerintah daerah. Pada LKPD Kabupaten Minahasa Utara TA 2013 terdapat temuan adanya penggunaan langsung atas Pendapatan dana kapitasi askes sosial yang berakibat pendapatan retribusi jasa umum dan belanja barang jasa kurang disajikan pada LRA.

Pemeriksa BPK menjelaskan PAD sudah diatur jenis-jenis pendapatan pada Permendagri. Kalau pada formalnya dalam pencatatan harus sesuai dengan STS. Substansinya atas keselurahan kas yang diterima oleh pemerintah daerah. pendapatan harus dilakukan secara bruto dan harus diterima. Terkait pengunaan langsung PAD yang berlaku adalah Form over substance karena kita harus memperhatikan peraturannya seperti apa. Karena aturan penerimaan itu adalah kas yang harus masuk ke rekening pemerintah daerah terlebih dahulu. Dalam hal adalah kasus penggunaan langsung diungkapkan dalam temuan.

Sedangkaan terkait penggunaan langsung misalkan terkait uang yang telah masuk maka dapat dicatat pada sebagai pendapatan yang ditangguhkan. Seharusnya posisinya dalam kas di SKPD seandainya bila terdapat pendapatan yang digunakan langsung maka uang yang diterima langsung digunakan sebenarnya tidak dapat koreksi karena tidak ada bukti yang dapat digunakan karena bukti pencatatan tidak ada dalam hal ini untuk Pendapatan adalah STS sedangkan untuk belanja tidak ada jadi secara formal tidak bisa dicatat.

Atas penggunaan langsung pemeriksa tidak melakukan koreksi atas kasus tersebut. Pemeriksa menyarankan kepada pemerintah daerah untuk dijelaskan pada CaLK dan menjadi temuan pemeriksaan. Minimal Pembaca laporan keuangan daerah mengetahui terdapat pendapatan dari JKN atau jamkesmas itu sendiri.terkait penggunaan langsung kita tidak perlu melakukan koreksi. Atas hal tersebut cukup diungkapkan dalam temuan kepatuhan. Namun terdapat pendapat pemeriksa yang menyatakan penggunaan langsung hanya bisa diungkapkan dalam catatan pemeriksaan dan tidak dilakukan koreksi atau pengungkapan di CaLK.

Terkait pelaksanaan substansi mengungguli bentuk formal pada laporan realisasi anggaran tidak disepakati oleh peneriksa dalam penerapannya. Pemeriksa umumnya berpendapat pada LRA yang berlaku adalah Form over substance. Terkait PAD yang digunakan langsung pemeriksa hanya akan menyajikan atas pendapatan yang diterima oleh kas daerah saja serta tidak menyajikan pendapatan yang tidak dianggarkan walaupun secara substansi terdapat pendapatan yang diterima oleh instansi pemerintah daerah tersebut.

Terhadap kasus PAD yang digunakan langsung oleh SKPD maka kita melihat kembali pengertian pendapatan pada PSAP yaitu Pendapatan-LRA diakui pada saat diterima pada Rekening Kas Umum Negara/Daerah. Secara substansi maka pendapatan tersebut seharusnya harus ada dan diterima pada rekening kas umum daerah terlebih dahulu. Namun Pada IPSAP 02 diperoleh penjelasan bahwa Pendapatan kas yang diterima satker/SKPD dan digunakan langsung tanpa disetor ke RKUN/RKUD, dengan syarat entitas penerima wajib melaporkannya kepada BUN/BUD untuk diakui sebagai pendapatan negara/daerah. Atas Interpretasi tersebut maka prinsip substansi mengungguli bentuk formal dapat diterapkan terkait PAD yang digunakan langsung oleh SKPD selama SKPD tersebut melaporkan maka dapat dilakukan koreksi atas nilai pendapatan tersebut. Sehingga nilai PAD akan bertambah sesuai nilai penggunaan langsung pada laporan keuangan untuk selanjutnya dapat ditambahkan penjelasan pada catatan atas laporan keuangan untuk memberikan pemahaman yang lebih baik kepada para pengguna laporan keuangan.

Pemeriksa BPK menjelaskan belanja modal yang terkait belanja untuk pemerolehan aset dimana belanja harus melihat dari anggarannya. Perlakuan untuk belanja modalnya untuk formalnya harus sesuai belanja di SP2D. untuk kegiatan belanja yang volume pekerjaan tidak sesuai perjanjian tidak pernah dilakukan koreksi atas belanja. Walaupun terdapat penerimaan dana yang diperoleh kas daerah atas TGR namun tidak mengkoreksi nilai aset daerah tersebut. Formalnya belanja modal harus sesuai SPJ saja. Terkait kesalahan penganggaran tidak dapat dikoreksi kita mengungkapkan dalam temuan kepatuhan, Misalkan untuk asetnya maka dapat dilakukan koreksi atas nilai aset yang sebenarnya misalkan atas realisasi belanja 100\% namun nilai aset baru $90 \%$ maka dapat dilakukan koreksi atas nilai aset tersebut. Selama ini hanya diungkapkan dalam catatan pemeriksaan. Namun terkait kekurangan volume yang ada pembayaran seharusnya mengurangi nilai dari aset namun selama ini belum pernah dilakukan hal tersebut. 
Terhadap permasalahan belanja modal berupa nilai belanja modal yang tidak sesuai realisasi fisiknya atau belanja modal yang direalisaiskan untuk belanja lainnya maka terlebih dahulu kita dapat melihat pengertian dari belanja yaitu Belanja diakui pada saat terjadinya pengeluaran dari Rekening Kas Umum Negara/Daerah selanjutnya pengertian dari belanja modal yaitu pengeluaran anggaran untuk perolehan aset tetap dan aset lainnya yang memberi manfaat lebih dari satu periode akuntansi. Belanja modal meliputi antara lain belanja modal untuk perolehan tanah, gedung dan bangunan, peralatan, aset tak berwujud. Atas nilai belanja modal yang tidak sesuai realisasi fisiknya maka nilai tersebut tetap dicatat sebagai belanja modal walaupun secara substansi nilai fisik tidak sesuai nilai belanja. Atas nilai yang tidak sesuai koreksi dapat dilakukan yaitu dengan cara melakukan koreksi atas pengeluaran belanja (penerimaan kembali belanja) yang terjadi pada periode pengeluaran belanja dibukukan sebagai pengurang belanja pada periode yang sama. Apabila diterima pada periode berikutnya, koreksi atas pengeluaran belanja dibukukan dalam pendapatan- LRA dalam pos pendapatan lain-lain-LRA. Apabila realisasi atas anggaran belanja modal pada laporan keuangan bukan merupakan belanja modal maka dapat dilakukan koreksi sesuai subtansi belanja yang dilakukan. Hal tersebut akan meningkatan kualitas dari laporan keuangan dan mencapai tujuan penyajian laporan keuangan pemerintah sebagaimana disebutkan dalam Paragraf 9 PSAP 01 huruf c untuk menyajikan informasi yang berguna untuk pengambilan keputusan dan untuk menunjukkan akuntabilitas entitas pelaporan atas sumber daya yang dipercayakan kepadanya, sesuai huruf c yaitu menyediakan informasi mengenai sumber, alokasi, dan penggunaan sumber daya ekonomi.

Mengingat berbagai macam jawaban yang diberikan, serta dengan variasi yang cukup banyak atas prinsip substansi mengungguli bentuk formal sesuai dengan pertimbangan masing-masing,oleh karena itu, dapat disimpulkan bahwa ada auditor memang memiliki variasi dalam interpretasi prinsip substansi mengungguli bentuk formal yang terkandung dalam standar akuntansi pemerintahan dan dalam melakukan audit atas laporan keuangan pemerintah. Variasi ini tidak sesuai dengan harapan adanya prinsip dan standar akuntansi yang telah ditetapkan, yaitu bahwa pengguna standar akan membuat interpretasi yang sama atas standar akuntansi dalam ketiadaan aturan yang rinci dan spesifik.

\section{SIMPULAN DAN SARAN}

\subsection{Simpulan}

Pendapat pemeriksa meperlihatkan bahwa terkadang ada variasi dalam melakukan penafsiran enam kasus substansi mengungguli bentuk formal dalam standar akuntansi pemerintah didalam pemeriksaan laporan keuangan pemerintah. Kurangnya kesamaan pendapat dalam penilaian pemeriksa, menunjukkan bahwa dalam pendekatan berbasis prinsip akuntansi dalam penetapan standar yang berasumsi bahwa pertimbangan profesional oleh pemeriksa adalah seragam atas setiap pemeriksaan merupakan hal yang sangat sulit untuk diterapkan. Hal tersebut dapat mempengaruhi dalam pelaksanaan tugas pemeriksa dalam melaksanakan pemeriksaan laporan keuangan pemerintah.

\subsection{Saran}

Prinsip substansi mengungguli bentuk formal tetap dikembangkan dalam standar, tetapi atas prinsip substansi mengungguli bentuk formal untuk masing - masing akun diberikan materi penjelasan tambahan terhadap akun tersebut. Panduan tambahan dalam standar sehubungan dengan menafsirkan substansi mengungguli bentuk formal dalam setiap akun juga akan membantu akuntan dan auditor untuk memberikan tambahan informasi atas beberapa pengungkapan dalam laporan keuangan. BPK sebagai lembaga dapat memberikan suatu forum bagi pemeriksa sebagai wadah dalam membangun pengertian yang sama bagi pemeriksa didalam menerapkan substansi mengungguli bentuk formal. Akhirnya, pemeriksa perlu meningkatkan pendidikan profesional akuntansi.

Beberapa keterbatasan yang mungkin mempengaruhi hasil penelitian ini, dan bisa diperbaiki pada penelitian di masa yang akan datang diantaranya adalah terbatasnya jumlah responden yang digunakan dalam penelitian ini sehingga dapat saja tidak mewakili keseluruhan pendapat dari auditor yang melakukan pemeriksaan atas laporan keuangan pemerintah daerah. Selain itu Penelitian selanjutnya dapat memperluas cakupan objek laporan hasil pemeriksaan atas laporan keuangan pemerintah daerah tidak hanya di wilayah Sulawesi Utara.

DAFTAR PUSTAKA

Audit Quality Forum, 2005. Agency theory and the role of audit, Institute of Chartered Accountants in England \& Wales

Bill Maurer, 2010. Form versus substance: AAOIFI projects and Islamic fundamentals in the case of sukuk, Journal of Islamic Accounting Business Research Vol. 1 No. 1, 2010 pp. 32-41

Brian J. Arnold and Jinyan Li, 2010, Justice Bowman on Substance over Form, canadian tax journal.

Chariri, A. 2009. Landasan Filsafat dan Metode Penelitian Kualitatif, Fakultas

Ekonomi Universitas Diponegoro Semarang

Christopher Nobes, 2004. Rules-based Standards and the Lack of Principles in Accounting 
Deddi Nordiawan, Tswahyudi Sandi Putra, Maulidah Rahmawati, 2007, Akuntansi Pemerintahan, Salemba Empat, Jakarta.

Drs. Oetoet Wibowo, Ak, 1996, Dasar-dasar akuntansi pemerintah ( Akuntansi dana), PT Pradnya Paramita, Jakarta.

Eaton, Tim V; Routt J Robert, 1999, SEC Application of APB 29: Form Over Substance?; Journal of Corporate Accounting \& Finance.

http://inspektorat.purworejokab.go.id/aset-tetap-yang-tidak-memenuhi-definisi-aset-tetap

Jerry J. Weygand, Donald E Kieso, Paul D Kummle, 2007, Accounting Principles, Salemba empat, Jakarta.

Karhi Nisjar S., Ak., M.M, 1998, Aplikasi Akuntansi Pemerintahan di Indonesia, CV. Mandar Maju, Jakarta.

Mulyadi, 2002, Auditing, Edisi Keenam, Salemba Empat, Jakarta

Nur Hidayat, Subsatansi akuntansi: prioritas dalam pemeriksaan pajak

O. Amat,., J. Blake, and E.Oliveras, (1996), Spanish auditors and the True and Fair View, Working paper

Otley.1980. The Contgency Theory of management Accounting: Achievement and Prognoasis. Accounting Organization and Society, Vol 5 No 4 pp.413-428

Patton, M. (1990). Qualitative evaluation and research methods (pp. 169-186). Beverly Hills, CA: Sage

P.M. Spink dan C.A. Ong, 2004, Substance Versus Form: Anglo-Australian Perspectives On Title Financing Transactions, Cambridge Law Journal

Peraturan pemerintah Nomor 71 Tahun 2010, Standar Akuntansi Pemerintah, Jakarta.

Revrisand Baswin, 2000, Akuntansi Pemerintahan Indonesia, BPFE, Yogyakarta

Septiawan, Santana K., 2010, Metode Penelitian Kualitatif, Edisi Kedua, Yayasan Obor Indonesia, Yogyakarta.

Spradley, James P., 2007, Metode Etnografi, Edisi Kedua, Tiara Wacana, Yogyakarta.

Suwardjono, 2011, Teori Akuntansi perekayasaan Pelaporan Keuangan, BPFE, Yogyakarta.

Sukoharsono, E.G. 2009. Refleksi Ethnografi Kritis. Pilihan Lain Teknik Riset Akuntansi. Jurnal Akuntansi 4 (1): $91-109$

Undang-Undang Nomor 15 Tahun 2006, Badan Pemeriksa Keuangan, Jakarta.

Yongtao Hong, 2008, Do Principles-based Accounting Standards Matter? Evidance from the Adoption of IFRS in China, Tesis

Zapata, Sonia;Rybnik, Daniel;Gaido, Maria Florencia;Barreiro, Adrian, 2001, Substance over form in Latin America: Myth or reality?, International Tax Review. 